\begin{tabular}{|l|l|l||}
\hline \multicolumn{2}{|c|}{ PublisherInfo } \\
\hline \hline PublisherName & $:$ & BioMed Central \\
\hline \hline PublisherLocation & $:$ & London \\
\hline \hline PublisherImprintName & $:$ & BioMed Central \\
\hline \hline
\end{tabular}

\title{
Runt repression
}

\begin{tabular}{|l|l|l||}
\hline \multicolumn{2}{|c|}{ ArticleInfo } \\
\hline \hline ArticleID & $:$ & 4545 \\
\hline \hline ArticleDOI & $:$ & $10.1186 /$ gb-spotlight-20020801-01 \\
\hline \hline ArticleCitationID & $:$ & spotlight-20020801-01 \\
\hline \hline ArticleSequenceNumber & $:$ & 211 \\
\hline \hline ArticleCategory & $:$ & Research news \\
\hline ArticleFirstPage & $:$ & 1 \\
\hline \hline ArticleLastPage & $:$ & 2 \\
\hline \hline & & RegistrationDate : 2002-8-1 \\
\hline ArticleHistory & $:$ & OnlineDate \\
\hline \hline ArticleCopyright & $:$ & BioMed Central Ltd2002-8-1 \\
\hline \hline ArticleGrants & $:$ & \\
\hline \hline ArticleContext & $:$ & 130593311 \\
\hline \hline
\end{tabular}




\section{Jonathan B Weitzman}

Email: jonathanweitzman@hotmail.com

The transcription factor Runt can repress expression of the Drosophila segment-polarity gene engrailed (en) in the odd-numbered stripes of expression seen in the developing Drosophila embryo. In an Advanced Online Publication in Nature Genetics, Wheeler et al. describe a genetic screen for factors that potentiate Runt activity (Nature Genetics, 29 July 2002, doi:10.1038/ng942). They identified genomic regions that dominantly suppress Runt-induced lethality and identified associated genes. This screen led them to four genes that encode repressors: $d C t B P$, Groucho, Rpd3 and tramtrack (ttk). Analysis of engrailedexpression in the different genotypes led them to a two-step model for Runt repression. Initiation of repression by Runt requires co-operation with Ttk, whereas maintenance after the blastoderm stage requires interaction with dCtBP, Groucho and Rpd3.

\section{References}

1. Mechanisms of transcriptional regulation by Runt domain proteins.

2. Nature Genetics, [http://genetics.nature.com] 